\title{
The Students' Reading Competency on High Order Items in the Junior High School
}

\author{
Ni Wayan Eka Kusumadewi1 ${ }^{*}$, Dewa Komang Tantra ${ }^{2}$, I Gusti Ayu Lokita \\ Purnamika Utami ${ }^{3}$
}

1,2,3 English Language Education, Post Graduate Study Program, Ganesha University of Education, Singaraja, Indonesia

\begin{tabular}{l} 
A R T I C L E I N F O \\
\hline Article history: \\
Received 18 August \\
2020 \\
Received in revised \\
Form 06 September \\
2020 \\
Accepted 18 October \\
2020 \\
Available online 01 \\
November 2020 \\
\end{tabular}

Keywords:

Critical Reading, High

Order Items

\begin{abstract}
A B S T R A C T
Reading is important in language learning. Through reading a text, the students can develop their mind which makes them smarter in solving problem. This study aims to describe and compare the students' reading competencies on high order items across classes, text genres, and reading indicators. The design implemented was descriptive and comparative research. The population of this research was the seventh-grade students and the samples were four intact classes which determined through Cluster Random Sampling. The data were gathered by using Reading Competency Test. The collected data were then analysed descriptively and then inferentially by implementing a parametric statistic, namely central tendency measures, measures of dispersion, and simultaneous comparison. The result shows the students' reading competency categorized as poor reading competency and there was not significance different in students' reading competencies on high order thinking items across classes, text genres, and reading indicators because the significant value of one-way ANOVA on the students Reading Competency was 0.75. The significant figure was higher than 0.05 . As a result, the students reading competency in high order thinking items was not significant. Therefore, the null
\end{abstract} hypothesis was accepted. It can be drawn a conclusion that the students reading competencies on high-orderthinking items across classes, text genres, and reading indicators are in below average.

\section{Introduction}

Reading is an inevitable part of literacy because literacy is an ability to read and write (Akın et al., 2015; Ekorini, 2018; Jin et al., 2020; Karadağ, 2014). Reading is an interactive process between the reader and a text. In this process, the text is interacted by the reader as the readers tried to find the meaning to avoid misunderstanding in receiving information. Through reading a text, students can expand their mind which enables them to be critical in solving problems (Pan \& Wu, 2013; Rogiers et al., 2020; Semerci \& Sumerci, 2017).

Reading is an important in language learning (Karadağ, 2014; Wilson, 2016). Through reading a text, the students can develop their mind which makes them smarter in solving problem. Besides, reading also give the students a wide point of view and think as the observer to gain the meaning of a text which at last, the students will also develop their critical thinking. In addition, reading also can make the students gain more vocabulary and knowledge (Duran \& Yalçintaş, 2015; Wilson, 2016). Moreover, reading also helps the students to get more new information. In learning a foreign language, reading is likewise a skill that teacher simply expects learners to acquire (Abdel Halim, 2011; Brown, 2004). Reading in a foreign language helps the students become more comfortable with the words and grammatical rules that enable them to express their own thinking.

In the Junior and Senior High Schools in Indonesia, reading is geared toward the attainment of competency. According to the 2013 Curriculum, competency is broadly defined as a set of attitude, knowledge, and skills in comprehending the texts structures and contents (Kemendikbud, 2013). Despite of the new scientific-oriented curriculum deployed since 2013, the EFL students' reading competency has not been attained satisfactorily as expected. Nor the refinement of reading strategies were endeavoured since then. Many EFL students possessed deficiencies in reading. Data have shown clearly, the students' reading scores were declining over the years from 2012 to 2018 . When compared to other countries, 
Indonesia positioned lowest in the rank when they joined the Program for International Students Assessment (PISA) in three consecutive years, they are, 2012, 2015, and 2018 (Pratiwi, 2019; Rogiers et al., 2020; Schleicher, 2018).

In 2018, 79 countries participating in PISA. As reported in PISA, the Indonesian students' reading scores still showed deficiencies. The students' reading scores, when compared to other countries, were ranked on 72 out of 79 countries (Pratiwi, 2019). Moreover, their reading mean score dropped to 371 despite the new curriculum has been deployed for five years. The PISA's result proved that the scientific approach was really a failure in developing the students' reading competency, especially in finishing up high-order-thinking items because they are not practicing it continuously. They are still being practiced in the level of low order thinking, whereas the students should be accustomed to answering problem solving questions with a variety of sources, this activity can make the students are ready to face questions that are in the level of high order thinking (Indrilla, 2018; Kartikawati et al., 2015; Muhlison, 2011). If the students are already familiar with the high order thinking items, they will be easy in finishing up high order thinking level.

Memorizing is seen as a style of teaching learning process in Indonesia. Based on Bloom's Taxonomy, memorizing is in the level of $\mathrm{C} 1$ or it is categorized as low order thinking. Most of the teachers implement it as usual. This is one of the reasons why Indonesia always in below average based of PISA. The students must be familiarized with the questions beyond low order thinking which could make them ready for the next PISA. The purpose of PISA is to grow up the ability to think creatively, solve a problem critically, mastering technology, and adaptive thinking in a new era. She also stated that the students who have good literacy are expected to have the competencies of affective, cognitive, and psychomotor by thinking creatively to face the challenges of the $21^{\text {st }}$ century. The previous research mentioned critical reading was not a new term for students, this was proved the levels to how students understand it (Albeckay, 2014; Din, 2020; Silalahi, 2018). This research aims to investigate the students understanding of critical reading.

\section{Methods}

This study was mainly intended to investigate the students reading competency on high order items in the junior high school. Specifically, the present research was endeavored to describe and compare the students' reading competency, especially on high-order-thinking items in the Sekolah Menengah Pertama Negeri (SMPN) 1 Ubud. The reading competency was measured using high-order-thinking items beyond the cognitive domain levels of $\mathrm{C} 1, \mathrm{C} 2$, and $\mathrm{C} 3$; the affective domain levels of $\mathrm{A} 1$ and $\mathrm{A} 2$; psychomotor domain levels of P1 and P2. Affective domain of levels A3 and A4; psychomotor domain of levels P3, P4, and P5. The text genres studied were of two types, namely: descriptive texts about a person, an animal, a place, a procedure, and recount texts about a personal experience and an accident. The text indicators measured consisted of four aspects, namely the main idea, the specific ideas, the textual references, and the word meanings.

The design implemented in this present research was that of a descriptive and comparative research. Data were analyzed, firstly descriptively, and then, inferentially by implementing a parametric statistic, namely central tendency measures, measures of dispersion, and simultaneous comparisons across classes, text genres, and reading indicators, and Post-hoc multiple comparison.

The population of this present study was the seventh-grade students of SMP $\mathrm{N} 1$ Ubud in academic year 2019/2020 which consisted of 303 students and they were grouped into 8 classes altogether. However, all members of the population were impossible to be involved in the present study. Thus, representative samples should be selected for the purposes of the research. Technically, Cluster Random Sampling was used to select the sample. It was applied to randomly select a group, not individual. It was used lottery system in selecting the sample. Lottery system suggested that all members of population had the same opportunity to be selected as the samples of the research.

Data collection methods explain the research instrument, the instrument's validation, instrument's trial-outs, and the data collection process. In the present study, the instrument used to collect data was that of a Reading Competency Test. Reading competency is a set of attitude, knowledge, and skills (Buku Panduan Guru Kurikulum 2013, 2013). There are four indicators of reading competency, namely the main idea that is a complete simple sentence which illustrates the general idea of a text, specific ideas are detailed pieces of information containing in the paragraphs, textual references are pronouns in reference to specific nouns in the descriptive and recount texts, and word meanings are the implicational/psychological words/phrases' meanings (Latifa, 2018). In addition, validity is an important consideration in developing and evaluation an instrument to make an effective research. In this present research, the content validity of the instrument was established carefully. The Reading Competency Test 
was validated for its content validity. The instrument was judged independently by two language education experts. After the instrument was validated, it was tried-out empirically for readability, reliability, item difficulty, and item discrimination.

Data analysis method covers data analysis technique, and pre-requisite testing. There are two research questions, namely quantitative descriptions of the students' reading competency on the English descriptive and recount texts, and inferential analysis in terms of simultaneous comparison across classes, text genres, and reading indicators. Therefore, the techniques implemented for the two research questions are as follows.

\section{Result and Discussion}

\section{Results}

The present research was focused on two research questions. The first question is addressed to statistical descriptions of the students' reading competency. The second question is focused on simultaneous comparison of means across classes, text genres, and reading indicators on high-orderthinking items of descriptive and recount texts in Sekolah Menengah Pertama Negeri 1 Ubud. Both the descriptive and inferential analysis of the dependent variable was analysed across classes, text genres, and indicators. Through detailed description and analysis, a thorough mapping on the students' reading competency on high-order-thinking items of the two text types could be obtained. This strategy was developed to facilitate an effective guidance in nurturing the students' reading competency.

After the instrument was administered procedurally, the intended data gathered and analysed systematically. The students were tested on descriptive and recount reading texts through 1) administering the test items to different classes simultaneously, 2) the students worked independently on the test items for 80 minutes, 3) they completed the test and submitted to the researcher in due time. The research findings are reported in the following section.

The descriptive and comparative analysis for reading competency test on high order thinking items can be seen in Table 1 .

Table 1. Descriptive Statistics of the Students' Reading Competency

\begin{tabular}{clc}
\hline No & \multicolumn{1}{c}{ Statistics } & Descriptive Values \\
\hline 1 & Arithmetic Mean & 32.92 \\
2 & Range & 56 \\
3 & Standard Deviation & 13.03 \\
4 & Variance & 169.84 \\
5 & Standard Error & 1.05 \\
\hline
\end{tabular}

In general, Table 1 shows the students' reading competency mean score $=32.9$ out of the total reading competency score $=100$. Categorically, the students' reading competency in high-order-thinking items are poor texts about person's character, person's experience, person physical appearance, descriptive about movie, and descriptive about procedure, and recount texts about accident and incidence. The range of the reading competency is very wide (range $=56$ ). It means the variability of the reading competency is very wide (standard deviation $=13.03$; variance $=169.84$ ). Further analysis is conducted across classes. There four intact classes in which the students' reading competency on high-order-thinking items were measured. The results are shown in Table 2.

Table 2. Descriptive Statistics of the Students' Reading Competency Across Classes

\begin{tabular}{llcccc}
\hline \multirow{2}{*}{ No } & \multicolumn{1}{c}{ Statistics } & \multicolumn{4}{c}{ Descriptive Values and Class } \\
\cline { 3 - 5 } & & I & II & III & IV \\
\hline 1 & Arithmetic Mean & 34.21 & 31.78 & 34 & 31.78 \\
2 & Range & 44 & 44 & 56 & 52 \\
3 & Standard Deviation & 11.49 & 12.15 & 15.24 & 13.08 \\
4 & Variance & 132 & 147.84 & 234.43 & 171.19 \\
5 & Standard Error & 1.86 & 1.97 & 2.47 & 2.12 \\
\hline
\end{tabular}

The reading competency criteria as follows: if the mean score interval was in 86-100, it categorized as very good, 75-85 categorized as good, 56-75 categorized as enough, and 10-55 poor 
(Nurgiyantoro, 2013). Table 2 show the students' reading competency averages across classes. The mean scores of reading competency in class $\mathrm{I}=34.21$, class $\mathrm{II}=31.78$, class III $=34$, and class $\mathrm{IV}=31.78$. Based on the mean score above, it is categorically as the students' reading competency across classes was poor or could be said in low level.

The students' range scores disclose another interesting fact about the students' reading competency in Sekolah Menengah Pertama Negeri $1 \mathrm{Ubud}$. The variabilities of the reading competency scores vary across classes (variance in class I = 132.06; variance in class II = 147.86; variance in class III = 232.43; and variance in class IV= 171.19). When the students' reading competency on higher-orderthinking items is analysed based on the reading text types, the results are clearly shown in Table 3.

Table 3. Descriptive Statistics of the Students' Reading Competency across Text Genres

\begin{tabular}{|c|c|c|c|c|c|c|}
\hline \multirow{2}{*}{ Text Type } & \multirow{2}{*}{ Statistics } & \multicolumn{5}{|c|}{ Descriptive Values and Class } \\
\hline & & I & II & III & IV & Average \\
\hline \multirow{5}{*}{ Descriptive Text } & Arithmetic Mean & 17.05 & 14.84 & 16.84 & 14.31 & 15.76 \\
\hline & Range & 32 & 24 & 36 & 28 & 36 \\
\hline & Standard Deviation & 8.40 & 6.16 & 8.48 & 6.61 & 7.51 \\
\hline & Variance & 70.64 & 37.97 & 71.92 & 43.78 & 56.42 \\
\hline & Standard Error & 1.36 & 0.99 & 1.37 & 1.07 & 0.60 \\
\hline \multirow{5}{*}{ Recount Text } & Arithmetic Mean & 17.05 & 16.94 & 17.15 & 17.47 & 17.15 \\
\hline & Range & 28 & 32 & 36 & 32 & 36 \\
\hline & Standard Deviation & 6.93 & 8.13 & 9.79 & 9.27 & 8.52 \\
\hline & Variance & 48.15 & 66.10 & 95.92 & 85.98 & 72.61 \\
\hline & Standard Error & 1.12 & 1.31 & 1.58 & 1.50 & 0.69 \\
\hline
\end{tabular}

The arithmetic means of the students' reading competency could be ordered based on text types across classes as follows. First, the students' reading competency is the highest in class IV on the recount text $($ mean $=17.4)$, class III is the second highest $($ mean $=17.1)$, class I is the third highest $($ mean $=17)$ and the lowest is in class II (mean $=16.9$ ) on the recount text type.

When the students' reading competency on higher-order-thinking items is analysed based on the reading competency indicators, the results are clearly shown in Table 4.

Table 4. Descriptive Statistics of the Students' Reading Competency across Indicators

\begin{tabular}{llccccc}
\hline \multirow{2}{*}{ Indicators } & \multirow{2}{*}{ Statistics } & \multicolumn{4}{c}{ Descriptive Values and Class } \\
& & I & II & III & IV & Average \\
\hline Main Idea & Arithmetic Mean & 8.52 & 8.94 & 8.52 & 6.63 & 8.15 \\
Specific Idea & Arithmetic Mean & 10.52 & 8.42 & 9.68 & 10.42 & 9.76 \\
$\begin{array}{l}\text { Textual } \\
\text { Reference }\end{array}$ & Arithmetic Mean & 6.84 & 8.21 & 8.52 & 9.26 & 8.21 \\
$\begin{array}{l}\text { Word/Phrases } \\
\text { Meaning }\end{array}$ & Arithmetic Mean & 8.21 & 6.21 & 7.26 & 5.47 & 6.78 \\
& Standard Deviation & 11.49 & 12.15 & 15.24 & 13.08 & 13.03 \\
\hline
\end{tabular}

The data shows the specific students' reading competency based the reading competency's indicators, namely: main idea or a complete simple sentence which illustrate the general idea of a text; specific ideas or specific pieces of information containing in the paragraph; and textual reference or pronouns in reference to specific nouns in the text; and word meaning or denotative meaning. The reading indicators' means are calculated as $8.15,9.76,8.21$, and 6.78 respectively.

The main idea or a complete simple sentence which illustrate the general idea of a text could be concluded as poor or equal to 8.15. While the specific ideas or specific pieces of information containing in the paragraph could be concluded as poor or equal 9.76. Furthermore, the textual reference or pronouns in reference to specific nouns in the text could be concluded as poor or equal to 8.21. And finally, the word meaning or denotative meaning can be concluded as poor or equal to 6.78 .

When the arithmetic means of the students' reading competency are ordered from highest to lowest based on its indicators as shown in Table 4.9, the order is as follows. The students' reading competency of high-order-items on specific ideas is the highest. It means that the students have the ability to work on specific ideas of high-order-items, followed with textual reference, main idea, and word or 
phrases meaning. The largest variability in terms of reading competency indicators exists in the class III, followed by class IV, II and class I.

Table 5. Summary Anova of Reading Competency

\begin{tabular}{lccccc}
\hline \multicolumn{1}{c}{ Source } & Sum of Squares & df & Mean Square & F & Sig. \\
\hline Between & 204.63 & 3 & 68.21 & 0.39 & 0.75 \\
Within & 25290.95 & 148 & 170.88 & & \\
Total & 25495.58 & 151 & & & \\
\hline
\end{tabular}

The data in Table 5 showed that the significant value of one-way ANOVA on the students Reading Competency was 0.75 . The significant figure was higher than 0.05 . As a result, the students reading competency in high order thinking items was not significant. Therefore, the null hypothesis was accepted. It can be drawn a conclusion that the students reading competencies on high-order-thinking items across classes, text genres, and reading indicators in SMPN 1 Ubud are below average. Since the students reading competency in high order thinking items was found statistically insignificant, Post-hoc Multiple comparison using Tukey's HSD Test could not be continuously computed.

\section{Discussions}

Summarize, as what has been aforementioned that the present descriptive and comparative research was intended to investigate the students reading competency in high order thinking items in Junior High School students. There are two research question proposed in this study. The discussion focuses on the finding of the two proposed research questions. The first discussion is about the students' reading competencies on high-order-thinking items across classes, text genres, and reading indicators. Meanwhile, the second discussion focuses on the significant differences in the students' reading competencies on high-order-thinking items across classes, text genres, and reading indicators. Data were analysed, firstly descriptively, and then, inferentially by implementing a parametric statistic, namely central tendency measures, measures of dispersion, and simultaneous comparisons across classes, text genres, and reading indicators.

The data of the present study were collected by administering reading competency test in the form of multiple choice. There were four intact classes were assigning the reading competency test. The reading competency indicators, namely: 1) main idea that is a complete simple sentence which illustrates the general idea of a text, 2) specific ideas are detailed pieces of information containing in the texts, 3) textual references are inflectional forms of pronouns in reference to specific nouns in the text, and 4) word meanings are the word/phrase/sentence meanings. In addition, there were two different text genres; they were descriptive and recount. Thus, the data obtained from the result were descriptively and inferentially analysed.

Based on the result of the descriptive analyses on the mean score of the students reading competency, it can be obviously seen that the mean of the students' reading competency was below average. For the general result of the students' reading competency, it was found that the mean score was 32.9 , thus it categorized as poor reading competency since (Nurgiyantoro, 2013) stated if the score between 10-55 was categorized as poor. The range of the reading competency is very wide, it showed the range is 56. It means the variability of the reading competency is very wide with 13.03 of the standard deviation and 169.84 of variance. These finding slightly indicated that the students' reading competency on high-order-thinking items are poor on both the descriptive texts about person's character, person's experience, person physical appearance, descriptive about movie, and descriptive about procedure, and recount texts about accident and incidence.

Further analysis is conducted specifically across classes after the general analysis. There are four intact classes in which the students' reading competency on high-order-thinking items were measured. It can be seen that the mean scores of reading competency in class I $=34.21$, class II $=31.78$, class III $=34$, and class IV $=31.78$. Further discussion, the highest score of reading competency on high order thinking items was class I with the mean score 34.21. In addition, the mean score of class III was the second position, it was 34. However, the mean score of class II and IV with the same mean score was the lowest among four classes, the mean figures were 31.78. These finding slightly indicated that there was different achievement among the seventh-grade students in SMPN 1 Ubud. For instance, based on the mean score above, it is categorically as the students' reading competency across classes could be said in low level because the reading competency criteria as follows: if the mean score interval was in 86-100, it categorized as very good, 75-85 categorized as good, 56-75 categorized as enough, and 10-55 poor. Thus, 
the students' reading competency categorized as below average. In addition, the students' range scores disclose another interesting fact about the students' reading competency in Sekolah Menengah Pertama Negeri 1 Ubud. The variabilities of the reading competency scores vary across classes (variance in class I = 132.06; variance in class II = 147.86; variance in class III = 232.43; and variance in class IV=171.19).

After knowing the result of the students reading competency based on their class, it further analyse the students' reading competency on higher-order-thinking items based on the reading text types; descriptive text and recount text. First, descriptive text, the students' reading competency is the highest in class I on the descriptive text where the mean is 17 , class III is the second highest where the mean score is 16.8, class II is the third highest with the mean score of 14.8 and the lowest is in class IV with the mean score of 14.3 on the descriptive text type. Second, recount text, the students' reading competency is the highest in class IV on the recount text with the mean score of 17.4, class III is the second highest with the mean score of 17.1, class I is the third highest where the mean score is 17 and the lowest is in class II with the mean of 16.9 on the recount text type. These findings slightly indicated there were different achievements between descriptive text and recount text which the highest belong to recount text. In the other words, the achievement of recount text was better than descriptive text.

Next, the students' reading competency across indicators is briefly explain. There are four indicators of reading competency, namely the main idea that is a complete simple sentence which illustrates the general idea of a text, specific ideas are detailed pieces of information containing in the paragraphs, textual references are pronouns in reference to specific nouns in the descriptive and recount texts, and word meanings are the implicational/psychological words/phrases' meanings (Belet \& Dal, 2010; Kim \& Hannafin, 2011; Latifa, 2018). Based on the data recapitulation, it was found the mean score of the reading indicators was showing different achievement; main idea (8.15), specific idea (9.76), textual reference (8.21), and word/phrases meaning (6.78). The result reflected that they are good in finding the specific pieces of information containing in the text and finding the textual reference to specific noun in the text. While they are not good enough in finding the general idea of a text. Furthermore, they are worst in finding the denotative meaning because of the limited vocabulary they have. It is agreed by Korte Bruck (2010) who says a good reading competency needs the skills such as vocabulary and decoding skill. Finally, the most difficult one for them was finding the word meaning or denotative meaning of a text.

The inferential analysis which was applied in the present study was one-way ANOVA as the present study was intended to figure out the significant differences of the students' reading competency. The result of the calculation pointed out that the significant value was 0.75 . This significant figure was much higher than 0.05 . As a result, the students reading competency in high order thinking items was not significant. Therefore, the null hypothesis was accepted. It can be concluded that there was no statistically significant different of the students reading competency on high order items in SMPN 1 Ubud. Since the differences of the students' reading competency was found statistically insignificant; thus, post-hoc multiple comparison using Tukey HSD test could not be continuously computed.

This present research was intended to investigate the students' reading competency on high order items in the junior high school. In addition, it was intended to investigate the significant differences of the students reading competency on high order items in the junior high school. The data of the present research were mainly gathered through administering research instrument which was reading competency test in the form of multiple choice. The instrument was administered to the samples under investigation of reading competency.

Based on descriptive and inferential analysis, the result clearly pointed out that the students' reading competency on high order items in SMPN 1 Ubud categorized as poor. In addition, the result of the statistical analysis by using one-way ANOVA showed that there was no significant difference in the students reading competency across class, text genres, and reading indicators.

In line with the result of the present research, there are some possible ways to help the students to increase their achievement in reading competency. First, poor reading competency implies the teacher should assist the students to expose themselves and to practice as many as possible (Karadağ, 2014; Kim \& Hannafin, 2011). The more the students practice in the teaching learning process of reading; the better the result of their reading will be. Second, poor reading competency implies the teachers should train intensively and extensively in reading process in order the students have the ability in determining the main idea, specific idea, textual reference, and word or phrases meaning of both descriptive and recount texts (Akın et al., 2015; Din, 2020; Hashimoto et al., 2019; Wilson, 2016).

\section{Conclusion}

The conclusion of this present research can be briefly described. Based on the descriptive analysis, the students' reading competency on high order items in SMPN 1 Ubud was categorized as poor. 
As a result, the students reading competency in high order thinking items was not significant. Therefore, the null hypothesis was accepted. It can be concluded that there was no statistically significant different of the students reading competency on high order items in SMPN 1 Ubud.

\section{References}

Abdel Halim, S. M. (2011). Improving EFL majors' critical reading skills and political awareness: A proposed translation program. International Journal of Educational Research, 50(5-6), 336-348. https://doi.org/10.1016/j.ijer.2011.11.003

Akın, F., Koray, Ö., \& Tavukçu, K. (2015). How Effective is Critical Reading in the Understanding of Scientific Texts? Procedia - Social and Behavioral Sciences, 174, 2444-2451. https://doi.org/10.1016/j.sbspro.2015.01.915

Albeckay, E. M. (2014). Developing Reading Skills through Critical Reading Programme amongst Undergraduate EFL Students in Libya. Procedia - Social and Behavioral Sciences, 123, 175-181. https://doi.org/10.1016/j.sbspro.2014.01.1412

Belet, S.. D., \& Dal, S. (2010). The use of storytelling to develop the primary school student's critical reading skill: The primary education pre-service teacher's opinions. Procedia - Social and Behavioral Sciences, 9, 1830-1834. https://doi.org/10.1016/j.sbspro.2010.12.409

Brown, H. D. (2004). Language Assessment Principles and Action Practices. Longman.

Din, M. (2020). Evaluating university students' critical thinking ability as reflected in their critical reading skill: A study at bachelor level in Pakistan. Thinking Skills and Creativity, 35(January), 100627. https://doi.org/10.1016/j.tsc.2020.100627

Duran, E., \& Yalçintaş, E. (2015). Review of the Critical Reading Education in the Primary Schools1. Procedia - Social and Behavioral Sciences, 174, 1560-1566. https://doi.org/10.1016/j.sbspro.2015.01.788

Ekorini, P. Z. (2018). Efektivitas Cooperative Script dalam Pembelajaran Reading Skill pada Mata Kuliah Reading Comprehension II (Skripsi). STKIP PGRI Nganjuk.

Hashimoto, T., Hayashi, Y., \& Seta, K. (2019). Metacognitive inference activity support by visualizing eyemovement graph during critical reading. Procedia Computer Science, 159, 1995-2004. https://doi.org/10.1016/j.procs.2019.09.372

Indrilla, N. (2018). The Effectiveness of Scientific Approach And Contextual Teaching And Learning Approach In Teaching Writing. Lingua Cultura, 12(4), 405-413. https://doi.org/10.21512/lc.v12i4.4452

Jin, T., Liu, X., \& Lei, J. (2020). Developing an effective three-stage teaching method for collaborative academic reading: Evidence from Chinese first-year college students. Journal of English for Academic Purposes, 45, 100853. https://doi.org/10.1016/j.jeap.2020.100853

Karadağ, R. (2014). Primary School Teacher Candidates' Views towards Critical Reading Skills and Perceptions of their Competence. Procedia - Social and Behavioral Sciences, 152, 889-896. https://doi.org/10.1016/j.sbspro.2014.09.339

Kartikawati, Y., Fauziati, E., \& Hikmat, M. H. (2015). The Implementation of Scientific Approach In Teaching English At The Eight Grade Of Smp Muhammadiyah 10 Surakarta In 2014/ 2015 Academic Year: A Naturalistic Study. Muhammadiyah University of Surakarka.

Kemendikbud. (2013). Kerangka Dasar Kurikulum 2013. Kementerian Pendidikan dan Kebudayaan.

Kim, M. C., \& Hannafin, M. J. (2011). Scaffolding Problem Solving in Technology-enhanced Learning Environments (TELEs): Bridging Research and Theory with Practice. Computers and Education, 56(2), 403-417. https://doi.org/10.1016/j.compedu.2010.08.024

Latifa, N. (2018). Teaching Narrative Text by Using Preview, Question, Read, State, and Test (PQRST) Technique. English Education Journal (EEJ), 9(2), 243-260. https://repository.arraniry.ac.id/id/eprint/5351/

Muhlison. (2011). The effectiveness of contextual teaching and learning to teach reading comprehension (An experimental study at the eight grade students of MTs At-Thosari Kalirejo Ungaran Timur in 
academic year of 2010/2011). IAIN Walisongo.

Nurgiyantoro, B. (. (2013). Penilaian Pembelajaran Bahasa Berbasis Kompetensi. BPFE Yogyakarta.

Pan, C., \& Wu, H. (2013). The Cooperative Learning Effects on English Reading Comprehension and Learning Motivation of EFL Freshmen. English Language Teaching, 6(5), 13-27. https://doi.org/10.5539/elt.v6n5p13

Pratiwi, I. (2019). Efek Program Pisa Terhadap Kurikulum Di Indonesia. Jurnal Pendidikan Dan Kebudayaan, 4(1), 51-71. https://doi.org/10.24832/jpnk.V4i1.115

Rogiers, A., Van Keer, H., \& Merchie, E. (2020). The profile of the skilled reader: An investigation into the role of reading enjoyment and student characteristics. International Journal of Educational Research, 99(1). https://doi.org/10.1016/j.ijer.2019.101512

Schleicher, A. (2018). PISA 2018 Insight and Interpretation. Organization for Economic Co-operation and Development.

Semerci, N., \& Sumerci, Ç. (2017). The Effect of Teacher Candidates' Critical Literacy Levels on Their Media Literacy Levels. Universal Journal of Educational Research, 5(12A), 13-18. https://doi.org/10.13189/ujer.2017.05130

Silalahi, R. M. (2018). Assessing Students' Understanding Towards Critical Reading and Its Impacts Towards Their Lives. Indonesian Journal of English Education, 5(2), 191-203. https://doi.org/10.15408/ijee.v5i2.9532

Wilson, K. (2016). Critical reading, critical thinking: Delicate scaffolding in English for Academic Purposes (EAP). Thinking Skills and Creativity, 22, 256-265. https://doi.org/10.1016/j.tsc.2016.10.002 